\title{
KARYA ULAMA DALAM MEMBANGUN KEDAMAIAN DI KALIMANTAN BARAT
}

\section{The Muslim Scholars' Work in Building Peace in West Kalimantan}

\author{
Moh. Hasim \\ Balai Penelitian dan Pengembangan Agama Semarang \\ Jl. Untung Suropati Kav. 70 Bamban Kerep Ngaliyan Semarang \\ Telp. 024.7601327 \\ Email : hasimlitbang@yahoo.co.id
}

Naskah diterima tanggal 28 Desember 2012. Naskah direvisi tanggal 16 Januari 2013. Naskah disetujui tanggal 4 Pebruari 2013

\begin{abstract}
Abstrak
Penelitian ini dilatarbelakangi oleh kerawanan konflik etnik di Kalimantan. Ulama sebagai agen perubahan masyarakat memiliki peran penting dalam menyampaikan pesan budaya damai. Penelitian ini berupaya menjawab permasalahan: Apa yang menjadi latar konflik etnik di Kalimantan Barat dan bagaimana bentuk pesan damai yang disampaikan ulama dalam bentuk teks? Penelitian menemukan bahwa faktor budaya menjadi faktor utama yang melatarbelakangi konflik etnik di Kalbar selain faktor ekonomi dan ketidakadilan yang diciptakan oleh pola pembangunan politik di Kalbar. Respon teks ulama di kalangan pesantren masih condong pada persoalan-persolan klasik keagamaan seperti fiqih dan tauhid. Respon teks karya ulama dalam kaitannya membangun pesan damai banyak dimotori oleh ulama dalam kapasitas sebagai cendekiawan muslim.
\end{abstract}

Kata kunci: konflik, pesan damai, ulama, Kalimantan Barat

\begin{abstract}
The research was conducted based the potential ethnic conflict in West Kalimantan. The Muslim Scholar as the agent of change in society has the important role in conveying the peace culture messages. The research sought to answer the research issues: what causes the ethnic conflict in West Kalimantan are and how the forms of peaceful messages conveyed by Muslim scholars in form of text are. Besides the economic factor and the inequity resulted through the pattern of political development, the researcher found that the cultural factor was the main factor causing the ethnic conflict in West Kalimantan. The text responses of Muslim preachers among Islamic schools still tended to the issues classical religiousness such as Fiqh and Tauhid (the unity of God). Those text responses in relation to build the peaceful messages were initiated by the Muslim preachers as the capacity of Muslim scholars.
\end{abstract}

Keywords: conflict, peaceful messages, muslim preacher, West Kalimantan

\section{PENDAHULUAN}

$\mathrm{K}$ alimantan Barat (Kalbar) merupakan salah satu wilayah di Indonesia yang mempunyai keragaman etnik, agama, bahasa, dan budaya. Di wilayah ini terdapat beberapa etnik besar meliputi Dayak, Melayu, Bugis, Jawa, Madura, Tionghoa, dan lainnya. Keragaman Etnis di Kalbar ternyata menghasilkan kerawanan kerusuhan antar etnis. Dalam catatan sejarah antara tahun 1950 sampai 1999, di Kalimantan Barat (Kalbar) sekurangnya telah terjadi 27 kali konflik antar etnis yang melibatkan etnis Madura, dengan etnis lain yaitu Dayak dengan Melayu. Konflik menjelang keruntuhan pemerintahan orde baru (1997-1999) merupakan konflik terbesar yang melibatkan etnis Madura, Melayu dan etnis Dayak (Al-Qadrie, 1999: 2-4; Sudagung, 2008 : 108; Tamagola, 2007 : 9-15). 
Penanganan konflik yang pernah terjadi di Kalbar patut untuk disayangkan. Usaha untuk menata perdamaian kembali pada arah yang esensial kurang mendapat perhatian. Perdamaian yang terjadi hanya sebatas kulit luar dan tidak menjamin perdamain itu abadi. Kehawatiran-kehawatiran dalam benak masyarakat masih juga ada, hati masyarakat masih was-was, karena secara sosial penanganan konflik di Kalbar tidak menyentuh akar permasalahan. Penanganan konflik hanya sebatas mengisolasi salah satu pihak yang kalah untuk tidak lagi bersinggungan dengan pihak lawannya.

Dalam konteks membangun perdamaian sosial sebagaimana yang digagas oleh Bandura dalam teori sosial learnin, yaitu masyarakat yang hidup dalam ruang budaya sesungguhnya mengalami proses pembelajaran untuk tidak melakukan konflik atau menginginkan kedamaian. Untuk selanjutnya masyarakat dengan sendirinya berupaya untuk melepaskan diri dari unsur kekerasan dan berupaya untuk secara langgeng mempertahankan kedamain diantara pihak-pihak yang terlibat (Hergenhahn, 2008: 281).

Oleh karena itu, dalam rangka penanganan konflik, dibutuhkan sebuah upaya mengurai akar konflik etnik dari titik api permasalahan yang sebenarnya. Perdamaian akan lebih abadi, ketika kedamaian itu digali dari potensi internal budaya masyarakat itu sendiri. Dengan demikian, kearifan budaya menjadi bagian yang sangat penting untuk mengembalikan suasana damai secara alami, tanpa ada unsur pemaksaan. Kedamaian menjadi sebuah kebutuhan yang secara naluri disadari oleh pihakpihak yang bertikai, tanpa ada unsur rekayasa atau bahkan paksaan dari dunia luar.

Ulama (cendekiawan muslim) sebagai wakil dari umat Islam menempati posisi strategis sebagai agen yang dapat memberikan pemahaman pada umat (masyarakat) akan perdamaian. Posisi ulama penting dalam membangun perdamaian Kalbar disebabkan oleh isu konflik etnik di Kalbar sudah bersentuhan dengan isu-isu agama, seperti dalam mengidentifikasi kelompok. Melayu dan Madura selalu diidentikkan dengan Islam, sementara Dayak adalah kelompok yang bertalian dengan non Islambisa Kristen atau Kaharingan.

Oleh karena itu, penelitian terhadap pesan damai yang dilakukan oleh ulama dalam meminimalisir potensi konflik di Kalbar sangat penting dilakukan. Permasalahan yang di hadapi dalam penelitian yaitu : bagaimana latar belakang sosial potensi konflik di Kalbar dan bagaimana bentuk pesan damai yang disampaikan ulama dalam bentuk teks?.

Metode yang digunakan dalam penggalian data penelitian yaitu menggunakan pendekatan studi kepustakaan, yaitu menggali data dalam bentuk teks tertulis yang tersimpan di perpustakaan maupun personal yang terkait dengan pokok permasalahan yang diteliti. Metode ini dibagi dalam tiga tahap, yaitu tahap pengumpulan data, tahap penganalisisan data, dan tahap penyajian data.

Dalam tahap pengumpulan data peneliti memilih penggabungan dua metode pengumpulan data yaitu metode wawancara dan observasi. Teknik wawancara dilakukan melalui key informan. Observasi dilakukan untuk menemukan teks hasil karya ulama lokal di Kalimantan Barat, yaitu dilakukan pada tempat-tempat yang diduga kuat menyimpan sumber-sumber data tertulis seperti perpustakaan, lembaga arsip, perguruan tinggi maupun situs-situs internet.

Data teks yang telah terkumpul kemudian dipilah dengan cara menelaah secara kritis melalui pendekatan analisis wacana. Pengelompokan dilakukan sesuai dengan pola yang disusun, yaitu data yang bersifat pendukung, konteks sosial masyarakat di Kalbar, konflik-konflik yang pernah terjadi di Kalbar, budaya lokal yang dinilai memiliki nilai kearifan dan respon cendekiawan muslim terhadap kearian lokal itu.

Penyajian data dilakukan secara bertahap ketika penulis menemukan data yang sesuai dituangkan secara langung pada bagian-bagian sesuai dengan bagan atau sistematika penulisan. Pada awal data belum tersusun secara sistematis kemudian diuraikan sesuai dengan alur berfikir deskriptif dan induktif. Setiap kali mendapatkan data baru selalu dikembangkan dan juga dilakukan reduksi membuang data yang tidak diperlukan.

\section{Kajian Teori}

Dalam tinjauan antropologi, agama diidentikkan dengan hasil kreasi budaya manusia. Sehingga agama memiliki keterkaitan dengan kehidupan manusia dalam arti agama memberikan pengaruh dalam gerak perubahan sosial di masyarakat. Pengaruh agama sebagai faktor penggerak perubahan dalam dua pengertian yaitu pendorong atau penghambat gerak perubahan. Dalam posisi seperti ini, agama berada dalam dua sisi yang bersebrangan, yaitu pada satu sisi dapat 
menjadi penentang perubahan dan pada sisi lain dapat menjadi pendorong adanya perubahan sosial (Pals, 2001: 113-132).

Agama sebagai agen perubahan sosial, tentu tidak bisa lepas dari aktor individu yang ada dalam kelompok entitas masyarakat pemeluknya. Agama tidak bisa lepas dari pemuja-pemujanya, yang mempercayai ajaran kebenaran yang di bawanya. Agama dapat menjadi pandangan hidup yang memberikan pedoman bagi pemeluknya dalam menjalankan perintah-perintah Tuhan sebagai individu-individu yang taat.

Pada sisi lain, agama juga membangun sebuah kepercayaan kolektif dalam kehidupan bersama di sebuah masyarakat. Keberadaan agama tidak dapat dilepaskan dari kehidupan masyarakat. Agama sebagai kepercayaan kolektif dapat dikatakan terbentuk setelah adanya masyarakat. Agama tidak dapat dipandang sebagai kepercayaan individu belaka yang berusaha mengenali kekuatan di luar dirinya. Sosiolog seperti Robertson Smith dan Emile Durkheim memandang kemunculan agama secara positif sejalan dengan perkembangan masyarakat. Agama bukan semata-mata sebagai persolaan individu, akan tetapi representasi kolektif dari masyarakat (Siahaan, $1986: 65$ ).

Peran penting agama dalam memberikan rasa damai, tidak dapat lepas dari peran ulama yang berkedudukan sebagai perwaris nabi. Melalui ulama ajaran agama disiarkan agar kebenaran dapat membangun kedewasaan umat. Islam sebagai salah satu agama dalam memberikan tanggapan terhadap perubahan sosial tidak bisa lepas dari para ulama sebagai warasatul anbiya', pewaris para nabi. Ulama yang pada saat ini tidak lain adalah para pemikir dan sosok cendekiawan yang ahli bidang keagamaan dan ilmu-ilmu lainnya. Ulama dalam perkembangannya tidak hanya mereka yang hidup dalam lingkungan masjid, atau pesantren. Tetapi ulama telah berkembang pada sosok cendekiwan yang tidak hanya dalam dalam pengusaan ilmu keagamaan, tetapi juga memahami ilmu-ilmu lain.

Terkait dengan problem perdamaian di Kalbar, Burton menyatakan bahwa untuk mencapai perdamaian yang subtantif perlu sebuah upaya yang lebih mengarah pada subtansi permasalahan. Burton mengistilahkan upaya perdamaian itu dengan sebuah konsep resolusi. Resolusi tidak hanya sekedar sebuah "manajemen" konflik yang lebih berorientasi pada hasil, atau out put, entah bagaimana caranya. Resolusi adalah sebuah proses melihat sebuah permasalahan konflik dari berbagai aspek, sosial, politik, ekonomi atau bahkan budaya, dan memperhatikan pandangan pihakpihak yang terlibat, untuk mencapai sebuah solusi jangka panjang yang bersifat permanen. Sebuah perdamaian yang tercipta dalam konflik diharapkan tidak hanya menyentul pada level atas tetapi juga menyentuh dari tingkatan masyarakat (Burton, 1990 : 199-203).

Relevan dengan pendapat Burton, salah satu solusi yang ditawarkan dalam pembangunan budaya perdamaian di masyarakat adalah melalui pendekatan teori pembelajaran yang dikembangkan oleh Bandura. Prinsip ini secara ilmiah mengacu pada teori bahwa perubahan sosial yang terjadi di masyarakat akan senantiasa menuju pada titik kesetabilannya, yaitu suasana sosial yang mendukung masyarakat dapat mengembangkan potensi budayanya tanpa ada pertikaian dan tekanan dari pihak luar. Masyarakat akan berupaya, berkeinginan dan belajar secara alami hidup dalam kedamaian dan kesejahteraan.

\section{PEMBAHASAN \\ Pesan Damai Ulama Kalbar}

Syarif Ibrahim Al-Qadri dalam hasil penelian menyebutkan bahwa faktor budaya menjadi faktor yang dominan dalam penyebab konflik di Sambas selain faktor lain seperti ekonomi dan geografis. Budaya pendatang baru Madura ikut memberikan andil dalam menciptakan konflik Sambas. Sama halnya dengan kelompok etnis lain. Masyarakat Dayak sebelum perang dengan Madura, terlebih dahulu menggelar upacara adat perang. Orangorang Melayu Sambas mengaitkan tanda-tanda krisis (ketegangan sebelum konflik) dengan berkibarnya bendera gaib kerajaan Sambas di halaman keraton.

Dalam realitas sosial di masyarakat juga terjadi proses termarginalisasinya suku-suku lokal yang terlebih dahulu mendiami wilayah Kalbar dalam kompetensi ekonomi akibat dari pola pemerintahan yang sentralistik tanpa mengedepankan potensi dan kekayaan budaya daerah yang dituding ikut memberikan andil besar dalam menumbuhkan rasa ketidakadilan. Bagi dua etnis besar Melayu dan terutama Dayak, kehadiran pendatang dinilai sebagai ancaman yang akan merebut potensi ekonomi mereka. Dalam sejarah kekuasaan orde baru, potensi daerah seperti hasil hutan dan hasil tambang yang dikelola oleh swasta melalui $\mathrm{HPH}$ dirasa tidak memberikan perubahan secara ekonomi 
terhadap perbaikan kesejahteraan masyarakat lokal (Al-Qadrie, 2008: 30-35).

Dalam sebuah tesisnya, Al-Qadrie memberikan kesimpulan bahwa konflik-konflik yang terjadi di Kalbar di sebabkan oleh empat faktor utama yaitu 1) perbedaan budaya, 2) kompetensi sosial-ekonomi yang tidak berjalan sebagaimana mestinya, 3) peremanisme, mafiaisme, dan tindakan kriminal lainya, serta 4) struktur ketidakadilan yang berlaku di Kalbar. Dari keempat faktor utama terbebut, faktor perbedaan budaya menjadi faktor yang paling dominan dalam memunculkan konflik antara etnis di Kalbar, terutama konflik yang melibatkan etnis Madura dengan dua rivalnya yang lain yaitu Dayak dengan Melayu. Dalam kaitan kasus Sambas, Al-Qadri memberikan contoh budaya yang ikut memicu konflik yaitu: kebiasaan membawa senjata tajam. Pendirian tempat ibadah dan melaksanakan ibadah, pelaksanaan pernikahan, dan upacara ronggeng (Al-Qadrie, 1999b: 4-12).

Akan tetapi, selama ini nampak upaya-upaya resolusi kurang berhasil dilakukan. Konflik Kalbar yang terakhir (antara Melayu dengan Madura) dengan terpaksa di lakukan di relokasi pengungsi ke sejumlah tempat di Kabupaten Pontianak, karena tidak diterimanya kehadiran warga Madura di daerah asalnya, Kabupaten Sambas. Kenyataan ini menandakan bahwa upaya perdamaian belum bisa terwujud. Kedua belah pihak belum bisa melupakan kejadian yang membuat mereka bertikai. Mereka belum dapat menerima keadaan seperti dalam kondisi sebelumnya, hidup bersama dalam perbedaan.

Meski nampak berhati-hati, Azyumardi Azra juga memberikan kesimpulan terkait dengan penyebab konflik di Kalbar. Perbedaan budaya antar kelompok etnik menjadi faktor penting disamping ketidakharmonisan hubungan di antara mereka. Di Kalbar, secara umum masyarakat Madura di pandang agresif, keras kepala, dan licik, dan tidak menghormati budaya, kebisaan dan sensitivitas penduduk lokal. Demikian juga sebaliknya, dimata Madura, kebanyakan orang Dayak dipandang sebagai masyarakat yang tidak berperadaban, yang suka memburu kulit kepala manusia. Suasana yang menciptakan stereotipe negatif diantara kelompok etnis inilah yang menciptakan tidak hanya benturan kebudayaan, tetapi juga menciptakan permusuhan dan kebencian diantara mereka (Azra, 2003: 3-15).

Melihat faktor perbedaan budaya sebagai pemicu utama munculnya konflik, tentunya dalam upaya membangun perdamaian dibutuhkan pendekatan kebudayaan. Dikarenakan penelitian ini hanya memfokuskan pada kajian teks, maka akan dilihat terlebih dahulu perkembangan teks sebagai salah satu media dalam komunikasi antara budaya. Teks sebagai media komunikasi kebudayaan, juga akan berkaitan dengan sisi agama (Islam). Teks menjadi sangat efektif dalam membangun pesan sosial untuk memahami kebudayaan etnis lain. Dengan teks, intraksi sosial yang dihambat oleh kesenjangan budaya (seperti keengganan bergaul akibat stereotipe negatif) dapat terbangun, tanpa harus kontak dengan etnis yang lain. Kebudayaan teks menjadi sangat penting untuk membangun pemikiran, mengubah cara pandang, dan untuk mengenal kebudayaan lain.

Dari catatan sejarah, respon ulama pada perubahan sosial yang terjadi di masyarakat telah dimulai oleh ulama-ulama zaman dahulu. Posisi ulama pada masa lalu ini cukup responsif terhadap perkembangan pemikiran saat itu. Shaykh Ahmad Khatib Sambas (1802-1875), tidak hanya dikenal di kalangan ulama Melayu Nusantara sebagai seorang ulama sufi. Akan Tetapi kiprah beliau juga dikenal di dunia Islam pada zamannya, kususnya keberhasilan beliau memadukan dua ajaran tarekat besar yaitu Qadiriyah dan Naqsabandiyah melalui sebuah karya kitab tarekat Fath Al-Arifin (Mahrus, 2003: 3-10).

Perkembangan pemikiran Islam di Kalbar kemudian dilanjutkan oleh Pemikiran Fiqih Maharaja Imam Kerajaan Sambas, Muhammad Basiuni Imran (1885-1976). Muhammad Basuni Imrom dalam kiprahnya banyak merespon persoalan sosial umat Islam pada zaman itu Buku buku beliau diantaranya: Bidayah al-Tauhid fi $\mathrm{Ilm}$ Tauhid, Matbaiah al Ahmadiyah, Al-Nusus wa al Barahim, Tadhrir (Sabil al-najah fi Tarik al-Salah), Jalan Kelepasan pada Mengingati orang yang meninggalkan Sembahyang.

Buku karangan Basuni banyak diterbitkan di Singapura, kecuali Al-Nusus yang diterbitkan di Kairo Mesir. Khulasah Sirah al-Muhammadiyah, Nur al-Siraj fi Qissah al-Isra' wa al-Mi'roj, Kitab al-Janaiz, Tarjamaah Durus Tarikh al-Sharia - Dari karya-karya itu, Basuni cukup responsif terhadap persolaan sosial yang dialami umat pada waktu itu. Seperti persolaan salat Jumat yang banyak dipersoalkan oleh umat Islam di Sambas, perselisihan terjadi pada masalah jumlah bilangan jamaah salat Jumat.

Basuni memberikan penjelasan persoalan yang terjadi di masyarakat rujukan kitab fathul alQarib, Fathul al-Muin, dan I'anah al-Talibin, Iqna'. 
Dari referensi atau rujukan yang digunakan dalam kitab itu jelas menunjukkan adanya komunikasi keilmuan dengan ahli-ahli fiqih sebelumnya. Persoalan-persolan fiqih lain yang diungkap oleh Basuni diantaranya: hukum orang meninggalkan shalat, melafalkan niat dalam salat, dan talkin mayat (Rahmatullah, 2003: 80-91).

Ulama lain yang pernah dikenal di Kalimantan Barat yaitu Haji Ismail Mundu yang berhasil membangun daerah Teluk Pakedai wilayah Kubu (Kerajaan Kubu) sehingga mendapatkan kepercayaan dari raja Kubu untuk menjadi mufti. Keberhasilan Haji Ismail juga mendapat simpati dari ratu Belanda, Wilhel Mina. Pada waktu mengerjakan Ibadah haji yang ketiga, H. Ismail Mundu menyempatkan diri untuk mengajar di Masjidil Haram dalam sebuah perkumpulan bernama Jam'ut Thanasuh (Abbas, 2001: 42-56).

Pasca kemerdekaan Indonesia tahun 1945, kekuasaan kerajaan-kerajaan yang menaungi para mufti (ulama) di Kalbar menjadi redup. Kekuasaan kerajaan dengan kewenangan untuk mengatur rumah tangga sendiri dalam sistem swapraja, berubah dalam sistem pemerintahan setingkat kabupaten atau kota. Kerajaan-kerajaan di Kalbar kehilangan tata pemerintahan tradisional, yang berimbas pula pada otoritas ulama dalam mengatur kehidupan keagamaan masyarakat. Kiprah ulamaulama di Kalbar yang menjadi pemegang otoritas hukum agama lambat laun menurun seiring dengan menguatnya hukum formal negara. Lembagalembaga keagamaan yang selama ini bernaung dibawah kekuasaan kerajaan seperti pesantren atau kelompok-kelompok pengajian yang dipimpin oleh para mufti juga ikut redup tenggelam, dan tidak dapat berkembang.

Selama pemerintahan dua orde kepemimpinan di Indonesia, akibat dari politik pemerintahan yang menekan umat Islam perkembangan pemikiran umat Islam menjadi sangat lambat. Perkembangan pendidikan pesantren yang menjadi salah satu lembaga pencetak kader ulama dan pemikirpemikir Islam menjadi semakin mundur. Di Kalbar hampir-hampir tidak ada regenerasi ulama yang memiliki pemikiran luas seperti, Haji Ismail Mundu, Muhammad Hatib Sambas, atau Muhammad Basuni Imrom. Mata rantai ulama yang kritis dan produktif dalam berkarya mensikapi fenomena sosial menjadi terputus.

Geliat dunia pesantren di Kalbar mulai menunjukkan esistensinya kembali bersamaan dengan semakin kuatnya peran orang Madura di Kalbar. Secara kuantitatif, jumlah pesantren meningkat. Pesantren-pesantren mulai didirikan oleh kelompok-kelompok muslim Madura sekitar era tahun 80 an. Sampai saat penelitian dilakukan, hampir mayoritas pesantren di Kalbar adalah di pimpin oleh etnis Madura. Akan tetapi, dalam perkembangannya sebelum terjadi konflik etnik, pesantren sebagai basis pembangunan intelektual muslim justru tidak menunjukkan sikap yang lebih plural dan terbuka. Pesantren-pesantren Madura sangat jarang memiliki santri dari kelompok etnis lain. Bahasa pengantar dalam pendidikan juga menggunakan bahasa lokal Madura. Sehingga memunculkan stereotipe negatif dikalangan masyarakat, pesantren Madura cenderung ekslusif.

Semenjak program Bantuan Operasional Sekolah (BOS) digulirkan oleh pemerintah, pesantren di Kalbar pada umumnya mulai terjebak pada pola-pola pendidikan persekolahan dalam bentuk formal. Pesantren tidak lagi mengajarkan kitab-kitab klasik sebagai sumber keilmuan, akan tetapi lebih banyak mengadopsi pendidikan kesetaraan seperti SD/MI, SMP/MTs, SMA/MA. Ekslusivitas pesantren dengan pola pendidikan tanpa ada penanaman pemahaman pentingnya komunikasi lintas budaya, dan pemahaman terhadap tradisi lokal menjadikan pesantren tidak mampu menghasilkan kader ulama yang memiliki wawasan kebudayaan.

Melihat gejala seperti itu, tentu secara tidak langung dunia pemikiran Islam ikut mempengaruhi ektalase konflik di Kalbar. Terlebih lagi, kerusuhan-kerusuhan besar yang terjadi di Kalbar selalu melibatkan kelompok Etnis Madura yang nota benenya lahir dari kalangan Pesantren. Memang harus di sadari, bahwa tidak semua Madura menyukai atau mengeyam pendidikan pesantren. Akan tetapi stereotipe masyarakat yang mengidentikan Madura itu Islam, dan pesantren ikut menyumbang prasangka etnis.

Seiring dengan melemahnya pemikiran dunia Islam di pesantren, kalangan ulama pesantren juga menunjukkan perkembangan yang hampir sama. Ulama pesantren di Kalbar hampir-hampir tidak memiliki reproduksi teks yang dapat bersentuhan dengan realitas sosial atau persoalan-persoalan yang krusial sedang dihadapi oleh masyarakat. Produksi teks yang dihasilkan oleh pesantren masih dominan pada persoalan-persoalan klasik umat Islam seperti akidah dan pertentangan syariah, seperti terjemah 
kitab Safinatunnajah dan Sulam Taufiq, kitab Fiqih Ibadah, Fiqih Ibadah Praktis dan Mudah: Matan Safinah Najah, Tahlilan, Bid'ah atau Sunnah, Nahwu, Risalah Ahlu Sunnah wal Jamaah.

Disayangkan, di antara teks yang diproduksi oleh kalangan pesantren ditemukan satu teks yang kontra produktif dengan upaya membangun perdamaian di Kalbar yaitu berjudul Memilih Presiden Pria Muslim. Dalam teks ini salah satu diantaranya mengutip ayat Alquran suart Alimron ayat 118 dan dilanjutkan dengan surat al-Baqoroh 120. Penulis memberikan penjelasan dengan nada propokatif bahwa seorang muslim dilarang memilih sosok pemimpin dari luar tokoh Islam alias kafir. Penulis buku menuturkan:

“Tapi fenomena yang terjadi di negara kita ini menunjukkan kalau mereka (peneliti:orang kafir) itu sangat memusuhi Islam bukan sekedar dalam hati saja, terbukti banyak kita temukan pelanggaran-pelanggaran yang mereka lakukan dalam masalah dakwah atau penyebaran agama..."

Dalam konteks Kalbar yang multi etnik dan agama ini tentu tidak relevan dan bersebrangan dengan upaya untuk membangun perdamaian. Wacana terkait dengan syarat presiden harus orang muslim sangat bertentangan dengan situasi multi etnis. Apabila wacana ini bergulir dimasyarakat luas, tidak menutup kemungkinan akan merembet pada permasalahan daerah, seperti pemilihan gubernur atau bupati yang selama ini selalu diliputi oleh suasana konflik.

Kesadaran untuk membangun komunikasi teks sebagai media pertukaran budaya untuk membangun harmoni dan perdamaian di Kalbar saat ini diambil alih oleh kalangan ulama dalam kapasitas sebagai cedekiawan muslim (pemikir Islam) yang hidup di perguruan tinggi. Kebangkitan teks sebagai media dalam menyampaikan pesan buah pemikiran kalangan muslim nampak dari beberapa hasil tulisan dalam bentuk buku, artikel maupun teks-teks yang diterbitkan dalam bentuk buku, jurnal, dan di media masa. Beberapa tokoh cendekiawan muslim yang mulai membangun teks sebagai media komukasi, yaitu Pabali Musa, Baidhilah Riyadhi, Eka Hendry, Erwin Mahroes, HA Halim Ramli, Harjani Hefni, Moh. Haitami Salim, Muhammad Rahmatullah, Munawar M. Saad, Syafaruddin Usman, Syarif Ibrahim Al-Qadri, Yusriadi, Zulkifli Abdillah.

Wacana perdamaian yang digagas oleh para ulama (cendekiawan muslim) secara ekplisit telah muncul pada akhir 2009. Dalam buku yang berjudul Damai Antara Cita dan Fakta (Hermansyah ed.), Peace Building: Membentuk dan Membangun Perdamaian. (Syarif Ibrahim AlQadrie, 2004), Pendidikan Multikulturalisme sebagai Modal Sosial bagi Perdamaian di Kalimantan Barat (Syarif Ibrahim Al-Qadrie, 2005), Etnisitas di Kalimantan Barat (Hermansyah, 2004), Memahami Kesukubangsaan di Kalimantan Barat (Hermansyah, 2008), Kearifan Setempat (Lokal Wisdom) dan Multikulturalisme dalam Mewujudkan Kerukunan Umat Beragama (Syarif Ibrahim Al-Qadrie, 2009), Migrasi/Transmigrasi, Pluralisme, Multikulturalisme dan Potensikonflik di Kalimantan Barat : Faktir dalam peminaan Kerukunan Umat Beragama (Syarif Ibrahim Al-Qadrie, 2008),

Dalam karya-karya ulama sebagai sosok cendekaiwan muslim, Yusriadi memberikan gambaran perdamaian yang di alami oleh masyarakat Embau. Akulturasi Islam dengan kebudayaan lokal yang selama ini dipandang sulit ditemui di Kalbar, digambarkan oleh Yusriadi dalam bukunya Orang Embau:Potret Masyarakat Pedalamaan Kalimantan Barat. Orang Embau adalah potret harmoni kedupan Islam dengan budaya Dayak, cermin perdamaian. Dari Karya Yusriadi ini, nampak ada upaya untuk mencarirkan stereotipe kelompok etnis di Kalbar. Sebelumnya, Dayak selalu di Indentikan dengan non Islam. Sehingga Etnis Dayak yang masuk Islam dianggap telah masuk Melayu, atau menjadi Melayu.

Yusriati juga berupaya untuk mencairkan stereotipe negatif tentang budaya orang Madura. Madura yang selama ini diidentikkan dengan sikap eklusif dan kekerasan karena budaya carok, mencoba di luluskan. Budaya carok menurut Yusriadi tidak semata-mata nafsu membunuh. Akan tetapi adalah sikap untuk menjaga diri dan kehormatan. Karya Yusriadi terkait dengan Madura yaitu sebuah artikel dengan judul Mengenal Budaya Madura di Kalimantan Barat (Yusriadi, 2008: 35).

Eka Hendri adalah sosok cendekiawan muslim yang ikut membangun wacana perdamaian secara lebih terarah dengan konsep-konsep dan landasan teroritik lebih memadai. Pesan-pesan damai dalam buku Eka Hendri diantaranya: Sosiologi Konflik Telaah Teoritis Seputar Konflik dan Perdamaian, dan Memahami Konflik Etnis; kajian komparatif-teoritis atas sejarah konflik etnis (dalam : Damai Antara Cita dan Fakta, Hermansyah ed.) Dalam bukunya yang pertama, Eka Hendri memberikan uraian 
secara lebih jelas, bagaimana membangun usaha perdamaian melalui upaya resolusi konflik. Dalam tulisan ini pula, disebutkan pentingnya membangun tranformasi budaya, untuk mengalihkan budayabudaya negatif kearah yang lebih positif. Dan perdamaian akan tokoh ketiga dibangun di atas pilar-pilar budaya yang memiliki kearifan (Hendry Ar, 2009 : 45; Andasputra, 1999 : 34).

Sejalan dengan pemikiran Eka Hendri, usaha untuk mewujudkan perdamaian Terkait dengan kearifan lokal mendapat perhatian dan analisis secara lebih luas dilakukan oleh Ibrahim M. Saleh, dosen STAIN Pontianak. Dalam penelitiannya yang dilakukan oleh TIM bersama dengan Ridwan Rosdiawan, Zaenuddin Hudi. Dalam tulisannya yang berjudul Merajut Perdamaian di Kalimantan Barat. Ibrahim mengungkapkan adanya potensi keariafan lokal yang dapat dijadikan media dalam melakukan resolusi konflik etnik di Kalimantan Barat. Kerarifan lokal untuk masyarakat etnis Dayak yaitu adat pamabakng, basaru/nyaru sumangat, pengembalian kamang, naik nango dan tolak bala, dan untuk masyarakat melayu tepung tawar (Tamagola, 2007 : 10-35).

Sebagai pembanding, keterikatan tradisi lokal sebagai media dalam membangun damai di Kalbar ini juga mendapat perhatian lebih Yohanes Badri. Yohanes berpendapat bahwa pada setiap masyarakat sudah ada pola dan versi tersendiri dalam penyelesaian konflik. Pola dan versi itu bersumber dari budaya dan kepercayaan adat lokal yang diyakini. Pada masyarakat Dayak (Kanayantn) misalnya, terdapat pola dan versi kearifan lokal yang dapat menjadi sumber untuk menyelesaikan konflik etnik. Pranata adat ini telah digunakan secara turun temurun dalam menyelesaikan konflik yang bersifat domestik baik intra maupun inter-etnik (Bahari, 2005: 5-13).

Akan tetapi dalam perkembangannya, model resolusi konflik yang berasal dari adat lokal cenderung dianggap kuno dan ketinggalan zaman. Bahkan, penyelesaian konflik melalui adat dinilai menghambat setelah negara melalui aparat penegak hukum mengambil alih penyelesaian konflik. Akibatnya peran pranata adat sebagai model resolusi konflik mengalami kemunduran dan partisipasi masyarakat lokal menjadi rendah, sementara ketergantungan masyarakat pada para penegak hukum formal menjadi dominan. Di sisi lain untuk mewujudkan perdamaian yang hakiki diperlukan partisipasi masyarakat lokal untuk dapat menjadi pereda konflik secara lebih cepat tanpa melibatkan orang-orang dari luar komunitas (Abbas, $2001: 3$ ).

Seperti yang disarankan oleh John Paul Lederach (2003) dalam konsepnya tentang Transformasi Konflik (Conflict Transformation) bahwa setiap proses mencapai perdamaian yang berkesinambungan sebaiknya dapat menyentuh empat dimensi perubahan yang signifikan, yaitu dimensi perubahan yang ada tingkat personal, relasional, struktural, dan yang paling ideal adalah tingkat kultural, atau perubahan yang ada ditingkat pengetahuan budaya yang menjadi acuan bagi kelompok dalam bertindak (http://www. beyondintractability. org/bi-essay/ transformation).

Minimnya respon teks yang di wujudkan oleh kalangan ulama pesantren (sesuai pembahasan di atas) dalam melihat perubahan sosial di Kalbar tentu memberikan pengaruh terhadap pemahaman kalangan santri dan umat Islam terhadap etnis lain. Minimnya pembangunan kebudayaan teks dilakangan pesantren menandakan bahwa pertukaran budaya yang mengarah pada pemahaman budaya etnis lain melalui media tulis, sangat jarang terjadi. Akibatnya, kesalahan dalam memahami hubungan budaya yang dapat meningkatkan tingkat kecemasan yang dialami oleh masyarakat dalam membangun pola hubungan komunikasi diantara mereka.

Dalam sebuah teori komunikasi yang dikembangkan oleh Gudykunst menyebutkan bahwa kecemasan dan ketidakpastian adalah dasar penyebab kegagalan komunikasi pada situasi antar kelompok. Sehingga semakin tinggi tingkat ketidakpastian seseorang atau kelompok maka akan semakin rendah keberhasilan komunikasi yang hendak dilakukannya. Teori ini jika dikaitkan dengan analisa potensi konflik, kecemasan akan berkurang ketika seseorang atau kelompok mampu memahami kelompok lain melalui pertukaran teks sebagai media komunikasi lintas budaya. Sehingga dalam hubungan sosial, konflik akan semakin lemah ketika antar kelompok etnis atau individu mampu membangun komunikasi teks secara baik.

Oleh karena itu, pengalian wacana pemikiran dikalangan ulama dapat dijadikan media dalam membangun perdamaian masih perlu dilakukan, agar perdamaian di Kalbar dapat terwujud dan potensi konflik etnik semakin berkurang.

\section{PENUTUP}

Respon teks karya ulama dalam kaitannya membangun pesan damai manyak dimotori oleh 
ulama dalam kapasitas sebagai cendekiawan muslim yang yang mengabdi dalam lingkungan perguruan tinggi. Respon teks ulama di kalangan pesantren masih condong pada persoalan-persoalan klasik keagamaan seperti fikih dan tauhid belum dapat menyentuh persoalan-persoalan yang di hadapai oleh umat (masyarakat) di Kalimantan Barat.

Problem perdamaian di Kalbar lebih banyak disebabkan oleh faktor budaya sebagai faktor utama yang melatarbelakagi konflik etnik di Kalbar selain faktor ekonomi, dan ketidakadilan yang diciptakan oleh pola pembangunan politik di Kalbar. Oleh karena itu pemahaman wawasan multikulturalisme bagiulama, terutama ulama yang hidup dilingkungan pondok pesantren, di Kalimantan Barat sangat diperlukan untuk memberikan pemahaman akan arti pentingnya pemahaman budaya kelompok lain dalam menciptakan kerukunan.

\section{UCAPAN TERIMA KASIH}

Disadari bahwa penelitian karya ulama dalam membangun kedamaian di Kalimantan Barat didukungn oleh berbagai pihak, antar lain pemerintah daerah dan masyarakat Kaltim. Karenanya kami haturkan terima kasih atas segala bantuan pada proses pengumpulan data. Ucapan serupa dihaturkan kepada tim redaksi Al-Qalam yang telah melakukan seleksi, editing dan memuat tulisan ini dalam volume 19, semoga penelitian ini dapat memperkaya khazanah keilmuan, demikian halnya secara praktis dapat dijadikan rujukan dalam menata kehidupan bemasyarakat dan beragama yang damai di Indonesia secara umum dan di Kalimatan Barat secara khusus

\section{DAFTAR PUSTAKA}

Abbas, Rifa'i H. 2001. Strategi Dakwah Guru Haji Ismailzmundu, Mufti Kerajaan Kubu. Pontianak: Yayasan Haji Ismail Mundu.

Al-Qadrie, Syarif Ibrahim .2008. Potensi dan Dinamika Kebudayaan : Kontruksi dan Faktasosial, Sistem Nilai, Identitas dan Perspektif Budaya. Pontianak : Universitas Tanjungpura.

Al-Qadrie, Syarif Ibrahim. 1999a. Konflik Madura dan Melayu di Sambas. Laporan Penelitian Universitas Tanjungpura.

Al-Qadrie, Syarif Ibrahim. 1999b. Konflik Madura dan Melayu di Kabupaten Sambas. Ponianak: Universitas Tanjungpura.
Andasputra, Nico dan Stepanus Djuweng. 1999. Sisi Gelap Kalimantan Barat. Pontianak : Institut of Dayakology Research and Development (IDRD)

Azra, Azyumardi. 2003. Kerusuhan-Kerusuhan Massal yang terjadi di Indonesia Barubaru Ini : Kemunduran Nasionalisme dan Kemunculan Separatisme. Dalam : Konflik Komunal Indonesia Saat Ini. Leiden-Jakarta : INIS dan PBB.

Bahari, Y. 2005. Resolusi Konflik Antar Etnik Dayak dan Madura di Kaliman- tan Barat. Desertasi Universitas Tanjungpura Pontianak.

Burton, John. 1990. Conflict: Resolution and Provention. New York: St.Martin's Press

Hendry Ar, Eka. 2009. Sosiologi Konflik (Telaah Teoritis Seputar Konflik dan Perdamaian. Pontianak : Stain Pontianak Press.

Hergenhahn, B.R., Olson, Matthew H. 2008. Theories of Learning (Teori Belajar), edisi ke7. Jakarta: Kencana Prenada Media Group

Mahrus, Erwin dkk. 2003. Shaykh Ahmad Khatib Sambas. Pontianak: Untan Press.

Pals, Daniel L. 2001. Seven Theori of Religion : Dari Animisme EB. Tylor, Materialisme Karl Marx Hingga Antropologi Budaya C. Geertz. Yogyakarta : Qalam.

Rahmatullah, Muhammad. 2003. Pemikiran Fikih Maharaja Imam Kerajaan Sambas Muhammad Basiuni Imran (1885 -1976). Pontianak : STAIN Pontianak Press.

Siahaan, Hotman M. 1986. Pengantar ke Arah Sejarah dan Teori Sosiologi. Jakarta: Penerbit Erlangga.

Sudagung. Hendro Suroyo. 2008. Mengurai Pertikaian Etnis:Migrasi Swakarsa Etnis Madura di Kalimantan Barat. Instiut Studi Arus Informasi

Tomagola, Tamrin Amal dkk. 2007. Revitalisasi Kearifan Lokal Studi Resolusi Konflik di Kalimantan Barat, Maluku, dan Poso, ed. Alpha Amirrachman (ed). Jakarta : International Center for Islam and Pluralism (ICIP).

Yusriadi 2008. Mengenal Orang Madura di Kalimantan Barat, dalam : M.Nasir dkk. Khasanah Budaya Kalimantan Barat. Pontianak : Stain Pontianak Press.

Internet : http://www.beyondintractability.org/biessay/ transformation: Diakses tanggal 28 Mei 2012 